\title{
Animal Models in Pharmacology: A Brief History Awarding the Nobel Prizes for Physiology or Medicine
}

\author{
Catarina V. Jota Baptista ${ }^{a}$ Ana I. Faustino-Rocha ${ }^{b, c}$ Paula A. Oliveira ${ }^{c, d}$ \\ ${ }^{a}$ Departament de Medicina i Cirurgia Animals, Edifici V. Facultat de Veterinària, Universitat Autònoma de \\ Barcelona, Barcelona, Spain; 'bepartment of Zootechnics, School of Sciences and Technology, Évora, Portugal; \\ 'Centre for the Research and Technology of Agro-Environmental and Biological Sciences (CITAB), University of \\ Trás-Os-Montes and Alto Douro (UTAD), Vila Real, Portugal; 'Department of Veterinary Sciences, UTAD, \\ Vila Real, Portugal
}

\section{Keywords}

Nobel $\cdot$ Animal model $\cdot$ Medicine $\cdot$ Physiology

Pharmacology

\section{Abstract}

Background: The Nobel Prize of Physiology or Medicine (NPPM) has recognized the work of 222 scientists from different nationalities, from 1901 until 2020. From the total, 186 award researchers used animal models in their projects, and 21 were attributed to scientists and projects directly related to Pharmacology. In the most recent years, genetics is a dominant scientific area, while at the beginning of the 20th century, most of the studies were more related to anatomy, cytology, and physiology. Summary: Mammalian models were used in 144 NPPM projects, being rodents the most used group of species. Moreover, 92 researchers included domestic species in their work. The criteria used to choose the species, the number of animals used and the experimental protocol is always debatable and dependent on the scientific area of the study; however, the 3R's principle can be applied to most scientific fields. Independently of the species, the animal model can be classified in different types and criteria, depending on their ecology, genetics, and mode of action. Key-Messages: The use of animal models in NPPM awarded projects, namely in Pharmacology, illustrates their importance, need and benefit to improve scientific knowledge and create solutions. In the future, with the contribute of technology, it might be possible to refine the use of animal models in pharmacology studies.

(c) 2021 S. Karger AG, Basel

\section{Introduction}

Alfred Nobel was a chemist, inventor, entrepreneur, and industrialist of the 19th century, being one of the most notable men of his time. He was born in Stockholm in 1833 and one of his most recognized achievements was the use of nitroglycerin as an explosive and the way to control it. Before his death, he left virtually all his fortune to establish prizes for people from different nationalities who made the most compelling achievement for the global benefit, in the fields of chemistry, physics, physiology or medicine, literature, and peace among nations $[1,2]$.

According to his words, the Nobel Prize of Physiology or Medicine (NPPM) should be attributed to "the person who shall have made the most important discovery with- karger@karger.com www.karger.com/pha

(C) 2021 S. Karger AG, Base

Karger"
Correspondence to:

Paula A. Oliveira, pamo@utad.pt 
in the domain of physiology or medicine." Until today, 222 scientists awarded the NPPM from 1901 to 2020 [3]. According to the Foundation for Biomedical Research, 186 award researchers (from the 222 total) used animal models in their projects [4]. From the total of NPPM awards, 23 were attributed to scientists and projects directly related to Pharmacology and the use and test of different drugs and chemicals in order to treat diseases, infectious agents, and physical conditions [4].

Animal models are based on the principle of comparative medicine that animals share physiological, pathological, behavioral, or many more other characteristics with humans. Historically, it is possible to say that the use of animals for health purposes started in ancient Greece, $>2,000$ years ago, when anatomy and physiology were born as scientific fields [5].

The use of animal models in the projects recognized by the NPPM is more than illustrative of the importance and need of them to improve scientific knowledge. In this way, this review aims to analyze the use of animal models as essential tools for scientific development, especially in pharmacology, using the NPPM projects as examples of worldwide recognized scientific improvements considerably depends on those models.

\section{Diversity in Animal Modeling: Selected Species and Scientific Fields}

As mentioned above, 186 award researchers used animal models in their projects (Table 1). For instance, Emil Adolf von Behring, the 1st NPPM winner, in 1901, used horses, rabbits, and guinea pigs in order to discover a diphtheria treatment. In the same way, the 2020 winners, Harvey J. Alter, Michael Houghton, and Charles M. Rice choose the chimpanzee as a model to study the hepatitis C. Furthermore, most of the awarded discoveries required $>1$ species as an animal model, in different parts of their studies. In fact, 87 of the prized researchers needed $>1$ animal species in their award projects [4].

Almost all the medical and biological fields require the use of animal models. Over time, the 186 NPPM winners that used animal models in their research came from distinct areas of Physiology and Medicine. In the most recent years, genetics is a dominant scientific area, with a lot of prizes attributed in this area, as the discovery of a mechanism that allows mature cells to become pluripotent, by John B. Gurdon and Shinya Yamanaka, awarded in 2012 [102]. In contrast, at the beginning of the 20th century, the majority of the studies were more related to under-

Animals Models in Pharmacology: Nobel

Prizes stand the structure and function of different cells, tissues, organs, and systems. For example, Henry H. Dale and Otto Loewi won the NPPM prize in 1936 for describing the chemical transmission of nerve impulses, using animal models from 4 different taxonomic classes (cats, frogs, birds, and reptiles) [28]. Microbiology, immunology, radiology, biochemistry, and pharmacology represent other scientific areas where animal models are frequently used, also in studies developed by NPPM winners.

The species of animals used as models in projects recognized by the NPPM are very diverse. Considering the taxonomic classes, the mammalian class is the most used, since 144 recognized projects and winners used mammalian species in some part of their work, followed by the birds, used in 35 discoveries (Fig. 1, 2). However, among the years, due to public opinion and animal welfare concerns, more primitive tend to use, as insects and nematodes, comparing to mammalian species. Nevertheless, in some studies and scientific fields, mammals, including primates, are needed to reach the proper conclusions (Fig. 1) [115].

Regarding the use of mammalian species in NPPM recognized works, the order Rodentia, which includes rats, mice, and guinea pigs, is the most used as an animal model. In detail, 86 projects used rodents, 29 used dogs, and 27 required rabbits, being those the most common mammals used (Fig. 3). Considering the use of domestic species (namely dogs, cats, ruminants, horses, chickens, and turkeys), 92 of the researchers used at least one domestic animal model in their works (Table 1).

The use of animal models in different scientific areas has always been a topic of debate in multiple conferences, interviews, and discussions. In the same way, the criteria used to choose the species, the number of animals, used and the experimental protocol is always debatable [116]. Therefore, it can be challenging to understand what criteria are used by recognized scientists for choosing a species instead of others as animal model. August Krogh, who was also a NPPM winner, was one of the 1st scientists to argue that despite the number of animals used and the research conditions, there is always the "most convenient species" to study a particular biology issue. Currently, concrete criteria are suggested in the literature mostly based on empirical data and ethical arguments. Very recently, in 2020, Dietrich et al. [117] established a total of 20 criteria, divided into 5 clusters. Some of them include, for instance, the ease of supply, the financial considerations, and the cultural attributes, that can contribute to the use of rodents. On the other 
Table 1. NPPMs attributed to researchers that used animal models from 1901 to 2020 [6-114]

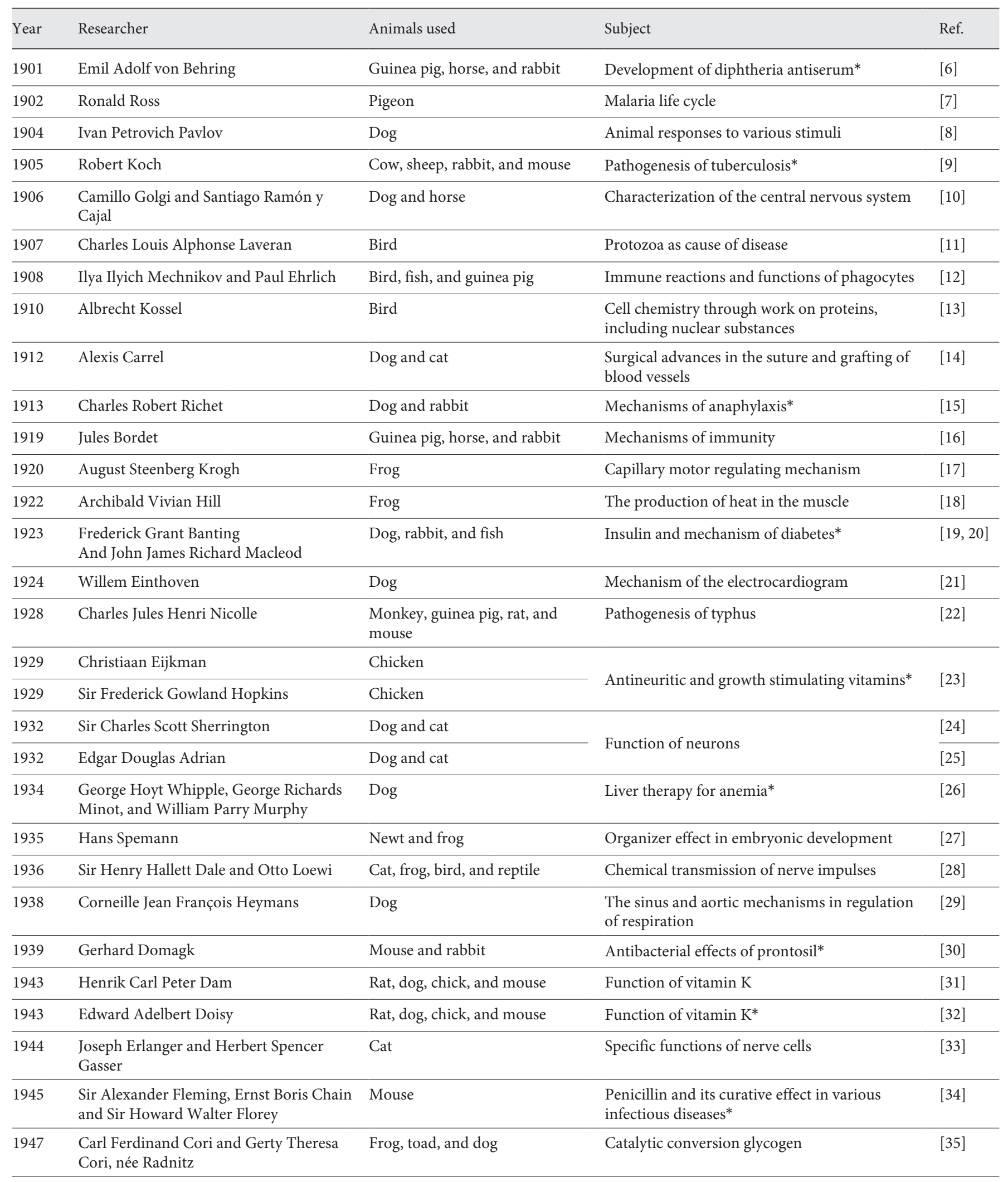


Table 1 (continued)

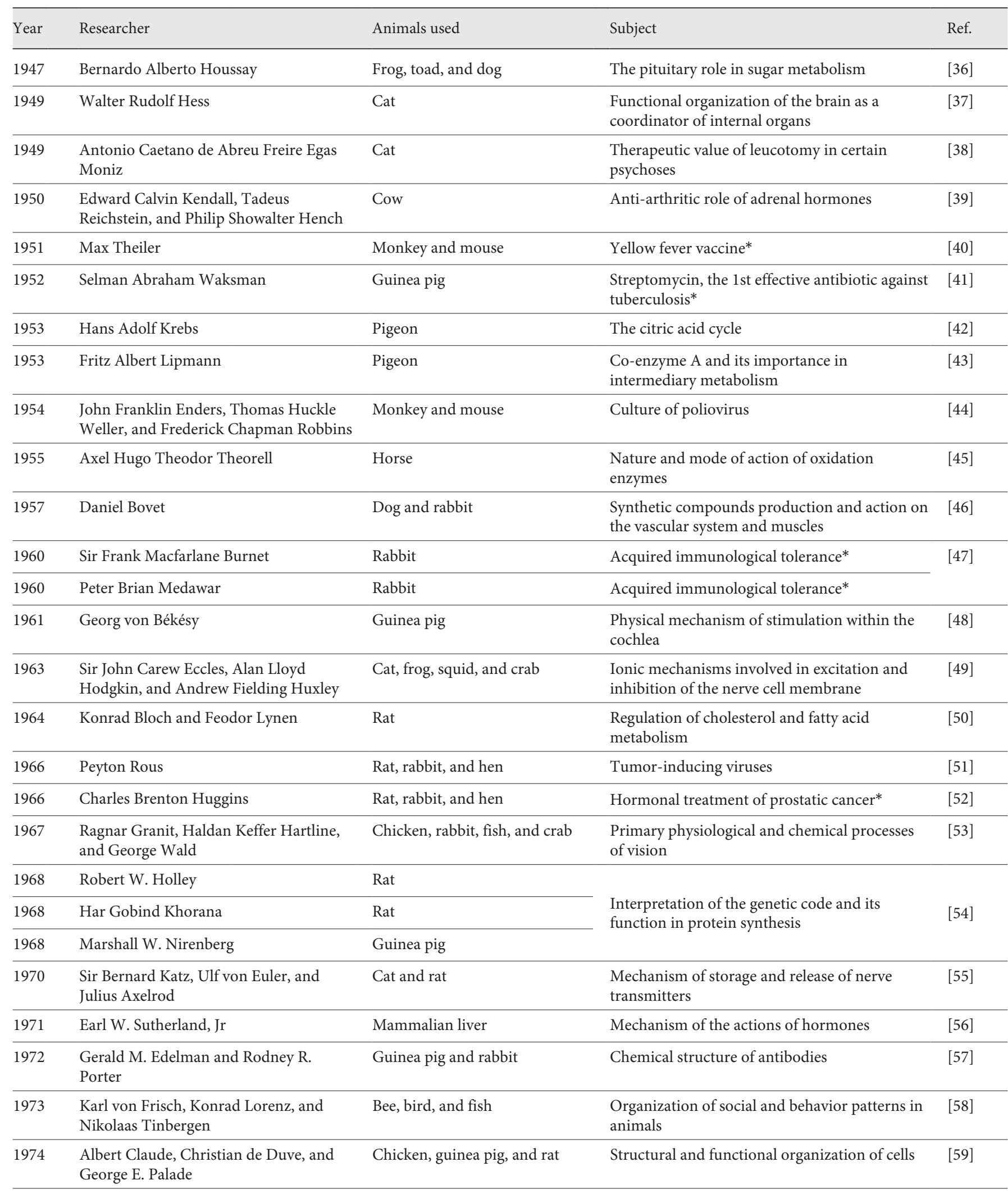


Table 1 (continued)

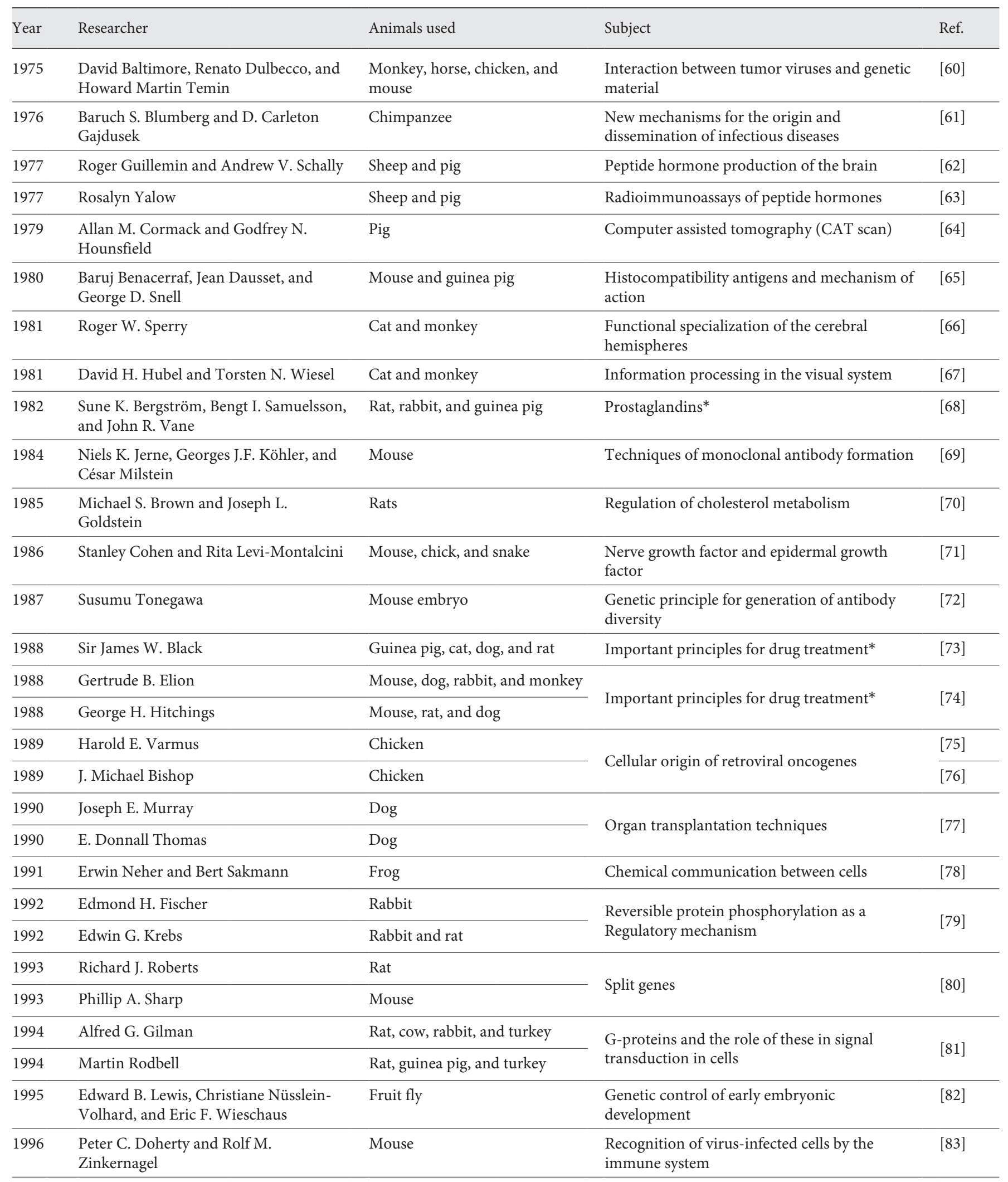


Table 1 (continued)

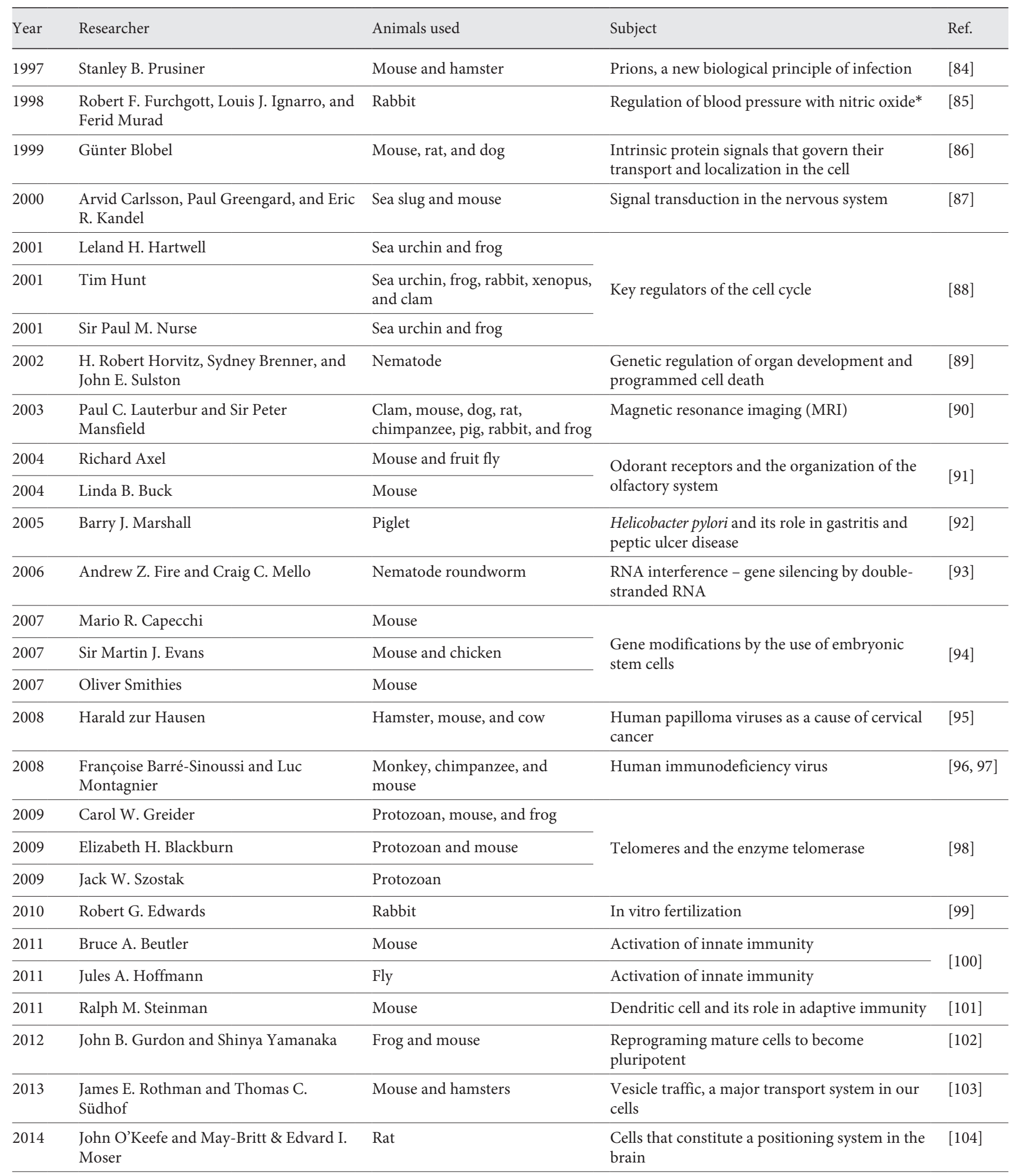


Table 1 (continued)

\begin{tabular}{|c|c|c|c|c|}
\hline 2015 & William C. Campbell and Satoshi Ōmura & $\begin{array}{l}\text { Mouse, dog, sheep, cattle, } \\
\text { chicken, and monkey }\end{array}$ & $\begin{array}{l}\text { Therapy against infections caused by } \\
\text { roundworm parasites* }\end{array}$ & [105] \\
\hline 2015 & Youyou Tu & $\begin{array}{l}\text { Mouse, dogs, sheep, cattle, } \\
\text { chicken, and monkey }\end{array}$ & Therapy against Malaria* & [106] \\
\hline 2016 & Yoshinori Ohsumi & Mouse & Mechanisms for autophagy & [107] \\
\hline 2018 & Dr. Tasuku Honjo and James P. Allison & Mouse & $\begin{array}{l}\text { Cancer therapy via inhibition of negative } \\
\text { immune regulation* }\end{array}$ & $\begin{array}{l}{[110,} \\
111]\end{array}$ \\
\hline 2019 & $\begin{array}{l}\text { William G. Kaelin, Jr., Gregg L. Semenza, } \\
\text { and Peter J. Ratcliffe }\end{array}$ & Mouse & How cells adapt to changing oxygen availability & [112] \\
\hline
\end{tabular}

Adapted from Foundation for Biomedical Research [3, 4]. NPPM, Nobel Prize of Physiology or Medicine. * Project related to pharmacology.

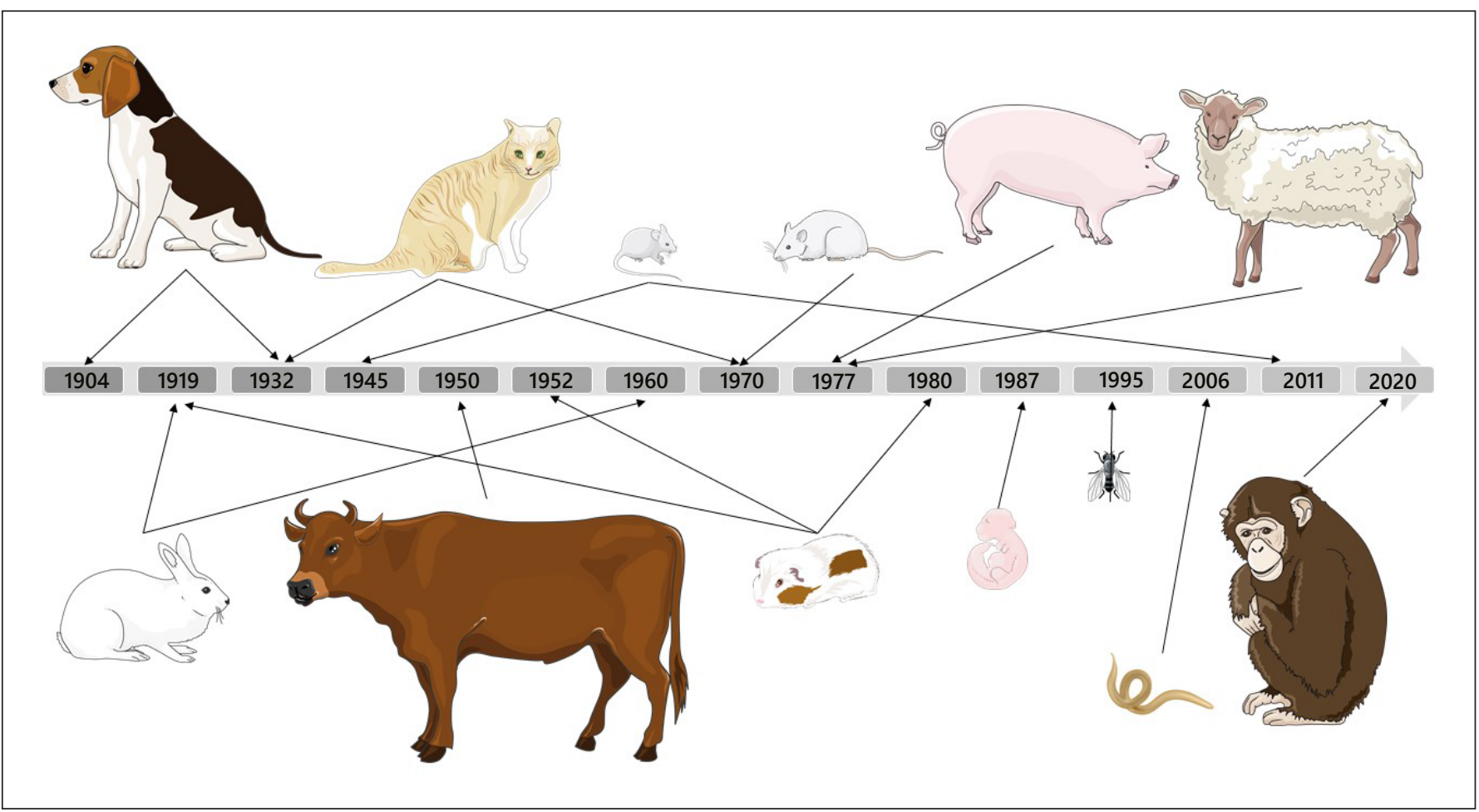

Fig. 1. Timeline illustrating some animal species used as models in NPPMs. NPPM, Nobel Prize of Physiology or Medicine.

hand, the researcher risks can be an explanation for the use of domestic species, and the comparative potential has a considerable impact on the choice of primates as animal models.
Moreover, some authors argue that the model choice depends on the biological area of the study and on the phase of the biological process. For example, in teratogenic studies, it is crucial to understand that embryonic 
Fig. 2. Groups of animals used as models in different NPPMs. NPPM, Nobel Prize of Physiology or Medicine.

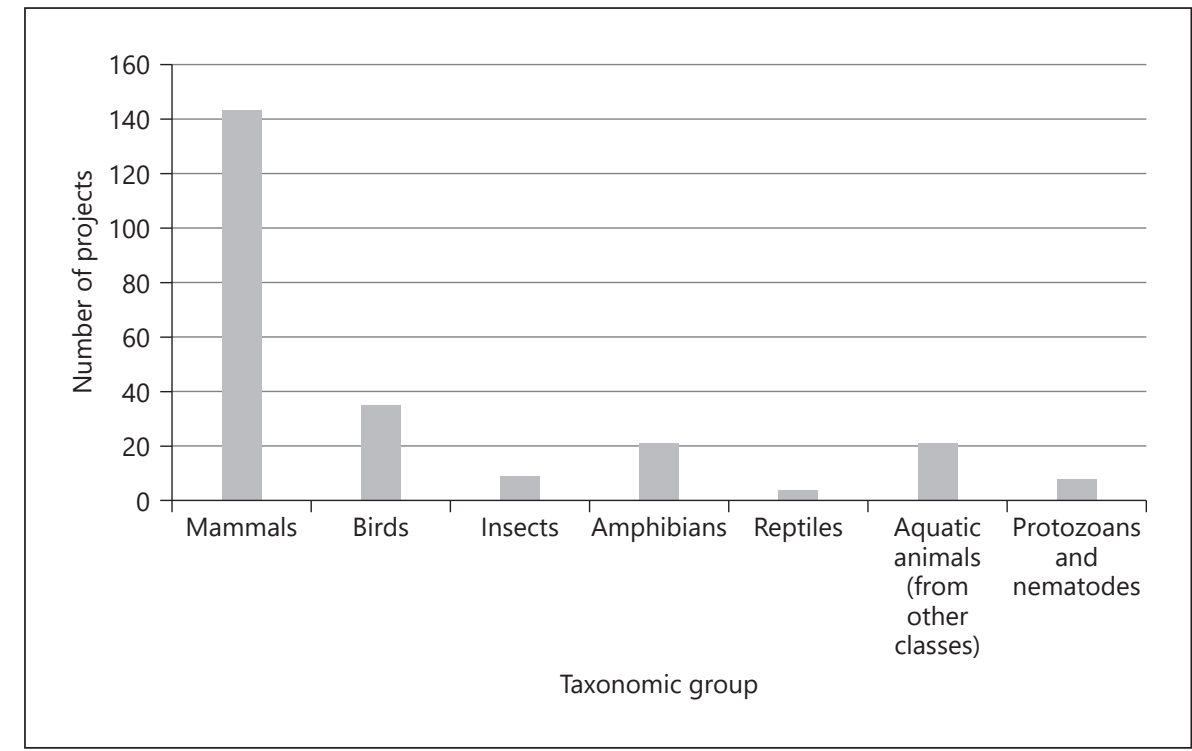

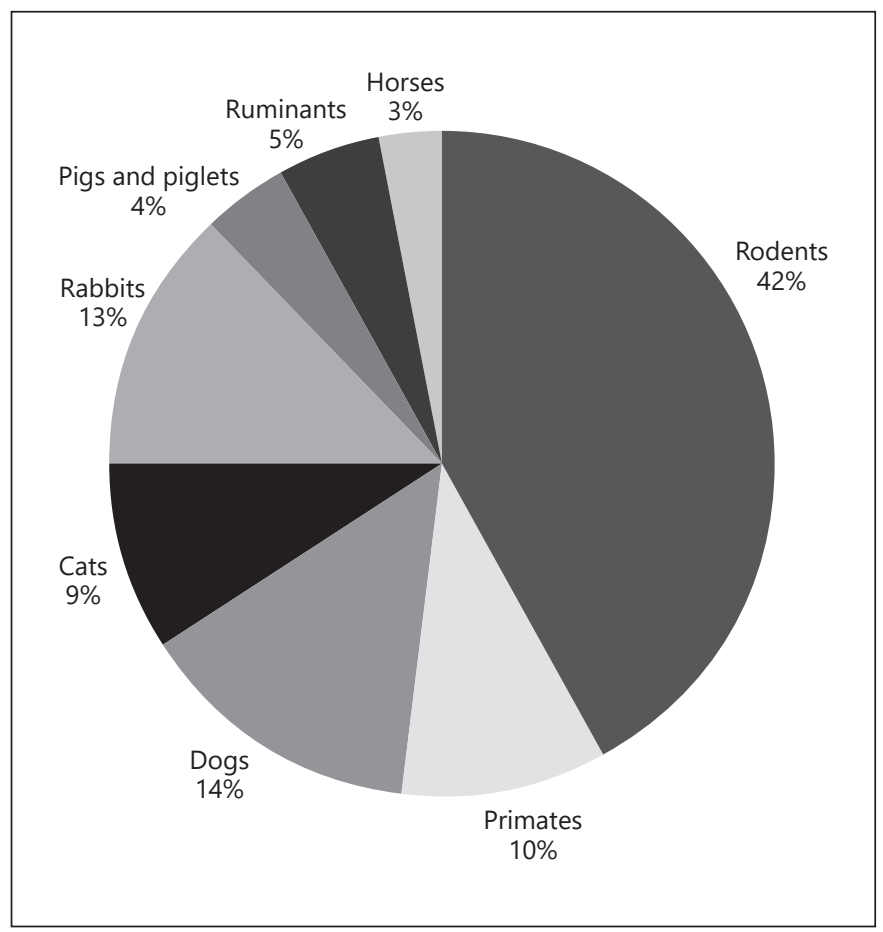

Fig. 3. Proportion of mammalian species used as animal models in NPPMs. NPPM, Nobel Prize of Physiology or Medicine.

development can be very distinctive among taxonomic groups and different phases of the development have distinct ideal animal models. In fact, invertebrates (as Caenorhabditis elegans and Drosophila melanogaster) are ad- equate for screening simple mechanisms in the early periods of the reproductive cycle, while mammalians, as rodents and rabbits, are phylogenetically closer to humans, allowing the possibility of taking better extrapolations and conclusions [118].

However, when choosing an animal model, it is not only essential to select the appropriate species but also the method to simulate a specific scenario. Thus, different types of animal models are usually defined in the literature and classified according to distinct criteria. Regarding their ecology or microecology, the models can be gnotobiotics, where the microbiota is totally known, germ free, where there is no microorganisms present, specific germ free, which means that the organism is free from specific bacteria or pathogens, or conventional, which is an animal with a normal microbiota [119]. On the other hand, according to genetics, they can be classified as outbred, defined as a closed population that are bred to maintain maximal heterozygosity, inbred, individuals of a particular species which are nearly identical to each other in genotype due to long inbreeding in order to preserve a characteristic, and transgenic, created by manipulating and adding a specific genetic material [120]. Finally, they can be categorized according to their mode of action. One of them is the induced model, where the studied condition is experimentally created in the animal and can be either through the exposition to chemical, biological or physical agents or surgically induced. For instance, the use of alloxan to kill the beta cells to study diabetes mellitus or the intestine reduction surgery to create a short- 
bowel syndrome model represent, respectively, examples of the 2 types of induced model [121, 122]. Furthermore, there is the negative model, which is referred to a species, strain or breed that does not develop a certain disease following an experimental treatment. This model is frequently used to study infectious diseases, which are often restricted to a limited number of susceptible species, being innocuous to the negative model [123]. Moreover, the orphan model is used to study a condition that occurs naturally in a nonhuman species but has not yet been described in humans. Finally, the spontaneous model is a mutant, a natural organism with a genetic variant, being the athymic nude mouse an example of this model, used to study heterotransplanted tumors and allowing the 1st description of natural killer cells [124].

In oncology, besides using induced models, by promoting carcinogenesis physically, chemically, biological, or hormonally, it's common to use models for cellular implantation. In this case, 4 different models using mice are frequently used (syngeneic, ectopic, orthotopic, and Hollow Fiber Assay [HFA]), all of them with advantages and disadvantages, following described. The syngeneic model is necessary to study anticancer drugs that interfere with the immune system, but it can often reduce the number of cell lines available. Even though the ectopic model promotes fast growth of the tumor, it does not allow the study of the interaction between the tumor and the primary tissue and metastasis. On the other hand, the orthotopic model permits a fast growth of the tumor, allows its study in natural microenvironment and possible metastasis. However, it usually is expensive and technically complex. Finally, although the HFA does not promote the microenvironmental interactions and is also complicated and costly, it has minimal effects on animal welfare, reduces the number of animals used and promotes fast results [125].

\section{Animal Use in Pharmacology NPPM-Awarded Studies}

From the total of NPPM awards, 30 are related to different areas of therapy. Concretely, as mentioned above, 21 were attributed to scientist and projects directly related to pharmacology, as the use and test of various drugs and chemicals in order to treat diseases, infectious agents, and physical conditions [4]. From those 21 pharmacology projects, 17 used animal models and are properly marked in Table 1. In the following paragraphs, we detail some of them, all very relevant on our 21 st century global society.
In 1905, Robert Koch won the NPPM for his tuberculosis studies, also presenting tuberculin as the 1st possible cure for tuberculosis. Before his studies on people with lupus vulgaris, a form of skin tuberculosis, performing skin injections of tuberculin and destroying the infected tissue, he also used cow, sheep, mouse, rabbit, and other species in different parts of his study to test his hypothesis $[9,126]$.

Frederick G. Banting and John J. R. Macleod were awarded in 1923 for their discovery of insulin, as a substance and the possibility of its use in diabetic patients. At 1st, dogs were used as an animal model. They created an extract from different dogs' pancreas and injected in a dog whose pancreas was surgically removed. Consequently, they observed a change in the dog's movements and behavior due to the dramatic decrease in their sugar levels [20, 127]. Nowadays, diabetes mellitus still requires animal models to be studied, especially rodents. To create an animal model of diabetes type I, the deficiency in insulin production is achieved by distinct mechanisms, from chemical ablation of the beta cells by streptozotocin to breeding rodents that spontaneously develop autoimmune diabetes, depending on the type of model, as mentioned above. Regarding animal models of type II diabetes, they tend to include models of beta cell failure or for insulin resistance. Additionally, many of them are obese, reflecting the human condition where obesity is closely linked to type II diabetes [127].

In 1939, Gerhard Domagk was recognized for his discovery of protosil. Domagk found, in 1932, that protosil was efficient in treating mice that were injected with a lethal dose of streptococci, and, 2 years later, was able to attribute that efficiency to sulfanilamide, as an active principle. Also concerning antibiotic therapy, Selman A. Waksman, in 1952, improved the Koch discoveries, mentioned above, to another level, by discovering that Streptomyces griseus suppressed the growth of tubercle bacteria. Its active principle, streptomycin, was also isolated after using guinea pigs as a model. Furthermore, Alexander Fleming, Ernst Boris Chain, and Howard Walter Florey were also recognized in this area of therapy, in 1945, for discovering penicillin and its potential as a treatment for multiple infectious diseases. After extracting the active principle from Penicillium rubrum and testing it in several concentrations in vitro Staphylococci, they needed to prove its efficacy in vivo, using mice $[34,128]$.

In 1988, Sir James W. Black, Gertrude B. Elion, and George $\mathrm{H}$. Hitchings were awarded for their research on antimetabolites of nucleic acid purines, leading to the development of a variety of drugs for the treatment of dif- 
ferent diseases. Thus, allopurinol is now used to treat gout and hyperuricemia, acyclovir is an antiviral drug that treats herpes virus infections, and azathioprine can be used to many immunological conditions and, for instance, to prevent organ transplant rejection. All of them, were frequently used in human and veterinary medicine nowadays and were previously tested in mice, rats, dogs, and small primates [74].

Finally, and more recently, in 2018, James P. Allison and Tasuku Honjo were recognized for their discovery of inhibition of negative immune regulation as a possibility of cancer therapy. Both of them identified proteins, with different modes of action, that release or activate our immune cells to attack tumors and both used mice as animal models in order to create a new oncologic therapy that proved to be effective [111].

\section{Animal Models: Social and Legal Evolution}

Historically, the use of animal models and the way they were used suffered remarkable changes associated with the concern to base these procedures on the current legal directives. From the Antiquity to the Renaissance, due to the taboos and religious issues on the dissections of humans, recognized physicians and scientists performed "vivisections," which is the exploratory surgery of live animals, without almost no social opposition or institutional regulations. Before the end of 17th century, there was already some opposition to vivisection. However, many scientists justified that their scientific undertakings were not cruel, basing themselves in the description of animals as "machine-like" by Renée Descartes. In 18th century, anthropocentric views on human duties to animals and philosophy question on their sensibility and suffering began questioning vivisections. Only in the 2nd half of the 19th century, due to a major medicine revolution, the use of animals in experiments began to require formal justifications and regulations. The publication of the Handbook for the Physiological Laboratory (1873) and the creation of Victoria Street Society for the Protection of Animals Liable to Vivisection (1875), later known as National Anti-Vivisection Society, illustrate those mental changes. In the 20th century, the concept of "animal ethics" emerged as a new field of bioethical studies and diverse ethical views on animals and of our duties toward them. However, public debate on animal research became polarized between animal rights activists and animal research advocates $[129,130]$.

The 3R's principles, established by Russell \& Burch in 1959 , were created to plan scientific studies that require

Animals Models in Pharmacology: Nobel

Prizes animal models and establish criteria for them. In a resume, the 3R's are referring to Replacement, Reduction, and Refinement. In other words, to replace the protected and more intellectually complex species to less sentient forms of life, cells, tissues, or computer models, if it is possible. To reduce the number of individuals used as much as possible to extract the necessary conclusions. Finally, to refine the procedures, ensuring the proper and ethical use of the animals and taking their health and welfare into account is essential $[131,132]$.

In 1999, in the 3rd World Congress on Alternatives and Animal Use in the Life Sciences, the Declaration of Bologna was signed and reaffirmed that "humane science is a prerequisite for good science, and is best achieved in relation to laboratory animal procedures by the vigorous promotion and application of the $3 R$ 's." Nowadays, animal research is developed in compliance with regulatory requirements which cover the inspection and licensing of animal sites, the training and competence of all the people involved in their manipulation and husbandry, and the mandatory authorization of every project by a competent authority upon ethical evaluation by an Animal Ethics Committee. The European Directive 2010/63/EU has set the regulatory framework for all animal research [133]. Moreover, the ARRIVE (Animal Research: Reporting in vivo Experiments) guidelines, established in 2010 and revised very recently, in 2020, provides practical and detailed instructions on the design of a research project, considering the sample size, husbandry, statistical analysis, and all the necessary aspects to plan a project. These guidelines are applied to all areas of research involving living animals from Drosophila or Caenorhabditis elegans to mammalian species [134].

\section{Conclusion}

We believe that the NPPM-awarded projects illustrate how animal models are essential for the advances in different subjects of biology and medicine, as in pharmacology or, more concretely, in antibiotherapy, endocrinotherapy, immunotherapy, and cancer therapy. However, we also consider that criteria for the use of animal models must be taken into account and applied in a practical context, according to the study area, species used, and selected type of model. Russel \& Burch 3R's criteria represent an example of simple, concise, and easy to remember criteria applicable to a variety of studies.

In the future, we believe that animal models will become more specific and informative to the different stud- 
ies, as they are continuously becoming in the past 100 years. Concretely in Pharmacology, the use of mathematical models and computer science will possibly allow the real time monitoring of the effect of an active principle tested on a live model, perhaps allowing the scientist to have complete and accurate results with a less quantity of animals used and minimizing the welfare concerns.

\section{Conflict of Interest Statement}

The authors have no conflicts of interest to declare.

\section{Funding Sources}

This work is supported by National Funds by FCT - Portuguese Foundation for Science and Technology, under the project UIDB/04033/2020.

\section{Author Contributions}

Catarina V. Jota Baptista wrote the paper. Ana I. Faustino-Rocha and Paula A. Oliveira supported the 1st author, correcting and revising the paper.

\section{References}

1 Lichtman MA. Alfred Nobel and his prizes: from dynamite to DNA. Rambam Maimonides Med J. 2017;8(3):e0035.

2 KENDALL EC. Alfred Nobel: the man and his prizes. Proc Staff Meet Mayo Clin. 1951; 26(23):417-23

3 NobelPrize.org. Facts on the Nobel prizes in physiology or medicine [Internet].

4 Foundation for Biomedical Research. Nobel prizes in medicine [Internet].

5 Ericsson AC, Crim MJ, Franklin CL. A brief history of animal modeling. Mo Med. 2013; 110(3):201-5.

6 Raju TNK. Emil Adolf von Behring and serum therapy for diphtheria. Acta Paediatr. 2006 Mar;95(3):258-9.

7 Sinden RE. Malaria, mosquitoes and the legacy of Ronald Ross. Bull World Health Organ. 2007 Nov;85(11):894-6.

8 Catania AC, Laties VG. Pavlov and Skinner: two lives in science (an introduction to B. F. Skinner's "some responses to the stimulus 'Pavlov"'). J Exp Anal Behav. 1999 Nov;72(3): 455-61.

9 Blevins SM, Bronze MS. Robert Koch and the "golden age" of bacteriology. Int J Infect Dis. 2010;14(9):e744-51.

10 de Castro F. Cajal and the Spanish neurological school: neuroscience would have been a different story without them. Front Cell Neurosci. 2019 May;13:187.

11 Laveran C Laureate pioneer of malaria. 2009; 50(7):657-8.

12 Schmalstieg FC, Goldman AS. Ilya Ilich Metchnikoff (1845-1915) and Paul Ehrlich (1854-1915): the centennial of the $1908 \mathrm{No}$ bel prize in physiology or medicine. J Med Biogr. 2008;16(2):96-103.

13 Jones ME. Albrecht Kossel, a biographical sketch. Yale J Biol Med. 1953 Sep;26(26):8097.

14 Sade RM. Transplantation at 100 years: Alexis carrel, pioneer surgeon. Ann Thorac Surg. 2005 Dec;80(6):2415-8.

15 Haas LF. Charles Robert Richet (1850-1935). J Neurol Neurosurg Psychiatry. 2001;70(2):255.
16 Bordet J. Traité de l'immunité dans les maladies infectieuses; 1939.

17 Poole DC, Pittman RN, Musch TI, Østergaard L. August Krogh's theory of muscle microvascular control and oxygen delivery: a paradigm shift based on new data. J Physiol. 2020 Oct; 598(20):4473-507.

18 Hill AV. The heat of shortening and the dynamic constants of muscle. Proc R Soc London Ser B - Biol Sci. 1938 Oct;126(843):136-95.

19 Banting FG, Best CH, Collip JB, Campbell WR, Fletcher AA, Macleod JJR, et al . The effect produced on diabetes by extracts of pancreas. Trans Assoc Am Physicians. 1922;37: $337-47$.

20 Tan SY, Merchant J. Frederick Banting (1891-1941): discoverer of insulin. Singapore Med J. 2017;58(1):2-3.

21 Cajavilca C, Varon J. Willem Einthoven: the development of the human electrocardiogram. Resuscitation. 2008 Mar;76(3):325-8.

22 Dworkin J, Tan SY. Charles Nicolle (18661936): bacteriologist and conqueror of typhus. Singapore Med J. 2012;53(53):764-5.

23 Carpenter KJ, Sutherland B. Eijkman's contribution to the discovery of vitamins. J Nutr. 1995 Feb;125(2):155-63.

24 Bennett MR. The early history of the synapse: from Plato to Sherrington. Brain Res Bull. 1999 Sep;50(2):95-118.

25 Adrian ED. Electrical activity of the nervous system. Am J EEG Technol. 1968 Mar;8(1): 25-36.

26 Minot GR, Murphy WP. Treatment of pernicious anemia by a special diet. JAMA. 1926 Aug;87(7):470-6.

27 Hamburger V, Hamburger V. Hans Spemann, Nobel laureate 1935. Neuroembryology. Boston: Birkhäuser; 1985. p. 384-7.

28 Dale H. Chemical transmission of the effects of nerve impulses. Br Med J. 1934 May; 1(3827):835-41.

29 Heymans C. The pressoreceptive mechanisms for the regulation of heart rate, vasomotor tone, blood pressure and blood supply. N Engl J Med. 1938 Aug;219(5):147-54.
30 Otten H. Domagk and the development of the sulphonamides. J Antimicrob Chemother. 1986 Jun;17(6):689-96.

31 Dam H, Schønheyder F, Tage-Hansen E. Studies on the mode of action of vitamin K. Biochem J. 1936 Jun;30(6):1075-9.

32 Doisy EA, Binkley SB, Thayer SA, McKee RW. Vitamin K. Science. 1940 Jan;91(2351):58-62.

33 Erlanger J, Gasser HS. The action potential in fibers of slow conduction in spinal roots and somatic nerves. Am J Physiol. 1930 Feb;92(1): 43-82.

34 Bennett JW, Chung KT. Alexander Fleming and the discovery of penicillin. Adv Appl Microbiol. 2001;49(49):163-84.

35 Cori GC. The role of glucose-1-phosphate in the formation of blood sugar and synthesis of glycogen in the liver [Internet].

36 Houssay AB, Pazo JH. Role of pituitary in the thyroid hypertrophy of pinealectomized rats. Experientia. 1968 Aug;24(8):813-4.

37 Hess WR. Causality, consciousness, and cerebral organization. Science. 1967 Dec;158(3806): 1279-83.

38 Moniz E. Prefrontal leucotomy in the treatment of mental disorders. Am J Psychiatry. 1937 May;93(6):1379-85.

39 Sulek K. Rok 1950 nagroda dla Edwarda Calvina Kendalla, Tadeusza Reichsteina i Philipa Showaltera Hencha za odkrycia dotyczace hormonow kory nadnercy ich struktury i biologicznego dliałania. Wiad Lek. 1968 Oct; 21(20):1885-7.

40 Theiler M, Smith HH. The use of yellow fever virus modified by in vitro cultivation for human immunization. J Exp Med. 1937 Jun; 65(6):787-800.

41 Schatz A, Waksman SA. Effect of streptomycin and other antibiotic substances upon mycobacterium tuberculosis and related organisms. Exp Biol Med. 1944 Nov;57(2):244-8.

$42 \mathrm{Krebs} \mathrm{HA}$. The citric acid cycle and the SzentGyörgyi cycle in pigeon breast muscle. Biochem J. 1940 May;34(5):775-9. 
43 Lipmann F. Metabolic generation and utilization of phosphate bond energy; 1941; p. 99162.

44 Weller TH, Enders JF, Robbins FC, Stoddard MB. Poliomyelitis viruses in tissue culture. Science. 1952;115(2998):3.

45 Theorell H. Nature and mode of action of oxidation enzymes. Science. 1956;124(3220): 467.

46 Bovet D, Carpi A. Pharmacological aspects of peripheral circulation. Annu Rev Physiol. 1958 Mar;20(1):305-38.

47 Ribatti D. Peter Brian Medawar and the discovery of acquired immunological tolerance. Immunol Lett. 2015 Oct;167:63-6.

48 Békésy GV. DC resting potentials inside the cochlear partition. J Acoust Soc Am. 1952 Jan 24(1):72-6

49 Birks R, Huxley HE, Katz B. The fine structure of the neuromuscular junction of the frog. J Physiol. 1960 Jan;150:134-44.

50 Bloch K, Vance D. Control mechanisms in the synthesis of saturated fatty acids. Annu Rev Biochem. 1977;46:263-98

51 Rous P, Beard JW. The progression to carcinoma of virus-induced rabbit papillomas (shope). J Exp Med. 1935 Oct;62(4):523-48.

52 Huggins C, Bergenstal DM. Inhibition of human mammary and prostatic cancers by adrenalectomy. Cancer Res. 1952;12(2).

53 Dowling JE. Nobel Prize: three named for medicine, physiology award. Science. 1967 Oct;158(3800):468-9.

54 Nirenberg M, Caskey T, Marshall R, Brimacombe R, Kellogg D, Doctor B, et al. The RNA code and protein synthesis. Cold Spring Harb Symp Quant Biol. 1966 Jan;31:11-24.

55 Nicholls M. Sir Bernard Katz. Eur Heart J. 2020 Jun;41(22):2045-7.

56 Sutherland EW, Rall TW. Formation of adenosine-3,5-phosphate (cyclic adenylate) and its relation to the action of several neurohormones or hormones. Acta Endocrinol Suppl. 1960 Oct;34(Suppl 50):171-4.

57 Porter RR. Chemical structure of gammaglobulin and antibodies. Br Med Bull. 1963 Sep;19(3):197-201.

58 Burkhardt RW. Patterns of behavior: Konrad Lorenz, Niko Tinbergen, and the founding of ethology. Chicago; 2005

59 Palade GE. An electron microscope study of the mitochondrial structure. J Histochem Cytochem. 1953 Jul;1(4):188-211.

60 Talbot SJ, Crawford DH. Viruses and tumours: an update. Eur J Cancer. 2004 Sep; 40(13):1998.

61 Zetterström R. Nobel prize to Baruch Blumberg for the discovery of the aetiology of hepatitis B. Acta Paediatr. 2008 Feb;97(3):384-7.

62 Brazeau P, Vale W, Burgus R, Ling N, Butcher M, Rivier J, et al. Hypothalamic polypeptide that inhibits the secretion of immunoreactive pituitary growth hormone. Science. 1973 Jan;179:77-9.

63 Berson SA, Yalow RS. General principles of radioimmunoassay. Clin Chim Acta. 1968 Sep;22(1):51-69.
64 Petrik V, Apok V, Britton JA, Bell BA, Papadopoulos MC. Godfrey Hounsfield and the dawn of computed tomography. Neurosurgery. 2006 Apr;58:780-7.

65 Dausset J, Hors J. Some contributions of the HL-A complex to the genetics of human diseases. Transplant Rev. 1975 Jan;22(1):44-74.

66 Sperry RW. Mental unity following surgical disconnection of the cerebral hemispheres. Harvey Lect. 1966 Jan;62:293-323.

67 Hubel DH, Wiesel TN. Receptive fields, binocular interaction and functional architecture in the cat's visual cortex. J Physiol. 1962 Jan; 160(1):106-54.

68 Funk CD. Prostaglandins and leukotrienes: advances in eicosanoid biology. Science. 2001 Nov;294(5548):1871-5.

69 Ribatti D. From the discovery of monoclonal antibodies to their therapeutic application: an historical reappraisal. Immunol Lett. 2014 Sep;161:96-9.

70 Brown MS, Goldstein JL. The SREBP pathway: regulation review of cholesterol metabolism by proteolysis of a membrane-bound transcription factor. Cell. 1997 May;89(3): 331-40.

71 Cohen S, Levi-Montalcini R. A nerve growthstimulating factor isolated from snake venom Proc Natl Acad Sci U S A. 1956 Sep;42(9): 571-4.

72 Tonegawa S, Steinberg C, Dube S, Bernardini A. Evidence for somatic generation of antibody diversity. Proc Natl Acad Sci U S A. 1974 Oct;71:4027-31.

73 Black J. A life in new drug research. Br J Clin Pharmacol. 2010 Sep;70(3):442-51.

74 Elion GB. Nobel lecture. The purine path to chemotherapy. Biosci Rep. 1989;9(5):509-29.

75 Varmus H. Retroviruses. Science. 1988 Jun; 240(4858):1427-35.

76 Bishop J. The molecular genetics of cancer. Science. 1987 Jan;235(4786):305-11.

77 Onaca NN, Levy MF, Sanchez EQ, Chinnakotla S, Fasola CG, Thomas MJ, et al. A correlation between the pretransplantation MELD score and mortality in the first two years after liver transplantation. Liver Transpl. 2003 Feb;9:117-23.

78 Neher E. Ion channels for communication between and within cells (Nobel lecture). Angew Chem Int Ed Engl. 1992 Jul;31(7):824-9.

79 Glass DB, Krebs EG. Protein phosphorylation catalyzed by cyclic AMP-dependent and cyclic GMP-dependent protein kinases. Annu Rev Pharmacol Toxicol. 1980 Apr;20:363-88.

80 Sharp PA. Split genes and RNA splicing. Cell. 1994 Jun;77(6):805-15

81 Gilman AG. Nobel Lecture. G proteins and regulation of adenylyl cyclase. Biosci Rep. 1995 Apr;15(2):65-97.

82 Duncan I, Lewis EB. Genetic control of body segment differentiation in Drosophila. Genes, development, and cancer: the life and work of Edward B. Lewis. Netherlands: Springer; 2007. p. 243-61.
83 Doherty PC, Zinkernagel RM. A biological role for the major histocompatibility antigens. Lancet. 1975 Jun;305(7922):1406-9.

84 Colby DW, Prusiner SB. Prions. Cold Spring Harb Perspect Biol. 2011 Jan;3(1):1-22.

85 Bian K. Nitric oxide (NO): biogeneration, regulation, and relevance to human diseases. Front Biosci. 2003 Jan;8:d264.

86 Rexach M, Blobel G. Protein import into nuclei: association and dissociation reactions involving transport substrate, transport factors, and nucleoporins. Cell. 1995 Dec;83(5): 683-92.

87 Furchgott RF. Endothelium-derived relaxing factor: discovery, early studies, and identification as nitric oxide (Nobel lecture). Angew Chem Int Ed. 1999 Jul;38(13-14):187080.

88 Nurse PM. Cyclin dependent kinases and cell cycle control. Biosci Rep. 2002;38(1314):487-99.

89 Ellis RE, Jacobson DM, Horvitz HR. Genes required for the engulfment of cell corpses during programmed cell death in Caenorhabditis elegans. Genetics. 1991;129(1): 79

90 Geva T. Magnetic resonance imaging: historical perspective. J Cardiovasc Magn Reson. 2006 Aug;8(4):573-80.

91 Stettler DD, Axel R. Representations of odor in the piriform cortex. Neuron. 2009 Sep; 63(6):854-64

92 Marshall B. Helicobacter pylori: 20 years on Clin Med. 2002;2(2):147-52.

93 Grishok A, Pasquinelli AE, Conte D, Li N, Parrish S, Ha I, et al. Genes and mechanisms related to RNA interference regulate expression of the small temporal RNAs that control C. elegans developmental timing. Cell. 2001 Jul;106(1):23-34.

94 Mak TW. Gene targeting in embryonic stem cells scores a knockout in Stockholm. Cell. 2007 Dec;131(6):1027-31.

95 zur Hausen H. Cervical carcinoma and human papillomavirus: on the road to preventing a major human cancer. J Natl Cancer Inst. $2001 \mathrm{Feb}$;93(4):252-3.

96 Gallo RC. Historical essay: the early years of HIV/AIDS. Science. 2002 Nov;298(5599): 1728-30.

97 Gallo RC, Montagnier L. The discovery of HIV as the cause of AIDS. N Engl J Med. 2003 Dec;349(24):2283-5.

98 Corey DR. Telomeres and telomerase: from discovery to clinical trials. Chem Biol. 2009 Dec;16(12):1219-23.

99 Edwards RG, Fishel SB, Cohen J, Fehilly CB, Purdy JM, Slater JM, et al. Factors influencing the success of in vitro fertilization for alleviating human infertility. J In Vitro Fert Embryo Transf. 1984 Mar;1(1):3-23.

100 Beutler B, Hoffmann J. Innate immunity. Curr Opin Immunol. 2004 Feb;16(1):1-3.

101 Steinman RM. The dendritic cell system and its role in immunogenicity. Annu Rev Immunol. 1991 Apr;9(1):271-96. 
102 Colman A. Profile of John Gurdon and Shinya Yamanaka, 2012 Nobel laureates in medicine or physiology. Proc Natl Acad Sci U S A. 2013 Apr;110(15):5740-1.

103 Südhof TC, Rothman JE. Membrane fusion: grappling with SNARE and SM proteins. Science. 2009 Jan;323(5913):474-7.

104 Langston RF, Ainge JA, Couey JJ, Canto CB, Bjerknes TL, Witter MP, et al. Development of the spatial representation system in the rat. Science. 2010 Jun;328(5985):1576-80.

105 Shen B. A new golden age of natural products drug discovery. Cell. 2015 Dec;163(6): 1297-300.

$106 \mathrm{Tu}$ Y. Artemisinin: a gift from traditional Chinese medicine to the world (Nobel lecture). Angew Chemie Int Ed. 2016 Aug; 55(35):10210-26.

107 Ohsumi Y. Yoshinori Ohsumi: autophagy from beginning to end. J Cell Biol. $2012 \mathrm{Apr}$; 197(2):164-5.

108 Katzenberg D, Young T, Finn L, Lin L, King DP, Takahashi JS, et al. A CLOCK polymorphism associated with human diurnal preference. Sleep. 1998 Sep;21(6):569-76.

109 Siwicki KK, Schwartz WJ, Hall JC. An antibody to the drosophila period protein labels antigens in the suprachiasmatic nucleus of the rat. J Neurogenet. 1992;8(1):33-42.

110 Chowdhury PS, Chamoto K, Honjo T. Combination therapy strategies for improving PD-1 blockade efficacy: a new era in cancer immunotherapy. J Intern Med. 2018 Feb; 283(2):110-20.

111 Sharma P, Allison JP. Immune checkpoint targeting in cancer therapy: toward combination strategies with curative potential. Cell. 2015;161(2):205-14.

112 Kaelin WG, Ratcliffe PJ. Oxygen sensing by metazoans: the central role of the HIF hydroxylase pathway. Mol Cell. 2008 May; 30(4):393-402.
113 Reed KE, Rice CM. Overview of hepatitis C virus genome structure, polyprotein processing, and protein properties. Curr Top Microbiol Immunol. 2000;242:55-84.

114 Bartenschlager R, Baumert TF, Bukh J, Houghton M, Lemon SM, Lindenbach BD, et al. Critical challenges and emerging opportunities in hepatitis $\mathrm{C}$ virus research in an era of potent antiviral therapy: considerations for scientists and funding agencies. Virus Res. 2018 Mar;248:53-62.

115 Sekimizu. Animal welfare and use of silkworm as a model animal. Drug Discov Ther. 2012 Aug;6(4):226-9.

116 Pasquali P. The importance of animal models in research. Res Vet Sci. 2018;118:144-5.

117 Dietrich MR, Ankeny RA, Crowe N, Green S, Leonelli S. How to choose your research organism. Stud Hist Philos Biol Biomed Sci. 2020;80:101227.

118 Alves-Pimenta S, Colaço B, Oliveira PA, Venâncio C. Biological concerns on the selection of animal models for teratogenic testing. Methods Mol Biol. 2018;1797:61-93.

$119 \mathrm{Al}$-Asmakh M, Zadjali F. Use of germ-free animal models in microbiota-related research. J Microbiol Biotechnol. 2015;25(10): 1583-8.

120 Houdebine LM. Transgenic animal models in biomedical research. Methods Mol Biol. 2007;360:163-202.

121 Ighodaro OM, Adeosun AM, Akinloye OA. Alloxan-induced diabetes, a common model for evaluating the glycemic-control potential of therapeutic compounds and plants extracts in experimental studies. Medicina (Kaunas). 2017;53(6):365-74.

122 Maria W, Peggy B, Johannes R, Julia S, Madeleine B, Robert J, et al. Establishing a short bowel model in mice as a tool for studying genetic risk factors of intestinal failure. Transplantation. 2017 Jun;101(6S2):S28.

123 Swearengen JR. Choosing the right animal model for infectious disease research. Animal Model Exp Med. 2018;1(1):100-8.
124 Hau J. Animal models for human diseases: an overview. Source book of models for biomedical research. Humana Press; 2008. p. 3-8.

125 Santos NP, Colaço AA, Oliveira PA. Animal models as a tool in hepatocellular carcinoma research: a review. Tumour Biol. 2017;39(3): 1010428317695923.

126 Hunter RL. The pathogenesis of tuberculosis: the koch phenomenon reinstated. Pathogens. 2020;9(10):1-25.

127 King AJF. The use of animal models in diabetes research. Br J Pharmacol. 2012;166(3): 877-94.

128 Hudson B, Boylan M. "The whole question of the future." The School of Pharmacy, University of London. Waltham, USA: Thermo Fisher Scientific; 2013. p. 107-37.

129 Henrique Franco N. Animal experiments in biomedical research: a historical perspective. Animals. 2013 Mar;3(1):238-73.

130 Regan T, Singer P. Animal rights and human obligations. Englewood Cliffs, NJ: Prentice Hall; 1989.

131 Sneddon LU, Halsey LG, Bury NR. Considering aspects of the 3 Rs principles within experimental animal biology. J Exp Biol. 2017; 220(Pt 17):3007-16.

132 Tannenbaum J, Bennett BT. Russell and Burch's 3Rs then and now: the need for clarity in definition and purpose. J Am Assoc Lab Anim Sci. 2015 Mar;54(2):120-32.

133 Barré-Sinoussi F, Montagutelli X. Animal models are essential to biological research: issues and perspectives. Future Sci OA. 2015 Nov;1(4):FSO63.

134 Percie du Sertid N, Ahluwaliaid A, Alamid S, Aveyid MT, Baker M, Browneid WJ, et al Reporting animal research: explanation and elaboration for the ARRIVE guidelines 2.0. PLos Biol. 2020 Jul;18(7):e3000411. 